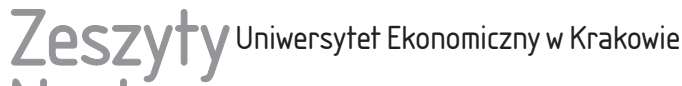 Naukowe
}

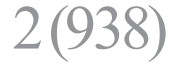

ISSN 1898-6447

Zesz. Nauk. UEK, 2015; 2(938): 87-100 DOI: 10.15678/ZNUEK.2015.0938.0207

Radosław Ślusarczyk

Studia Doktoranckie Wydziału Finansów

Uniwersytet Ekonomiczny w Krakowie

\section{Forward guidance jako narzędzie polityki pieniężnej w sytuacji stopy procentowej zbliżonej do zera}

\section{Streszczenie}

Ostatni kryzys finansowy oprócz negatywnych skutków gospodarczych przyniósł także liczne zmiany instytucjonalne. Nie ominęły one również niezwykle istotnej części polityki finansowej państwa, jaką jest polityka pieniężna. W sytuacji stóp procentowych zbliżonych do minimalnych poziomów banki centralne zaczęły poszukiwać nowych narzędzi prowadzenia polityki monetarnej. W artykule przedstawiono jedno z takich narzędzi, to jest forward guidance, jego teoretyczne podstawy funkcjonowania oraz charakterystykę. Artykuł zawiera także informacje na temat wykorzystania forward guidance w okresie kryzysu finansowego oraz analizę wyników badań empirycznych dotyczących efektów jego stosowania. Szczególną uwagę zwrócono na sposób implementacji forward guidance przez System Rezerwy Federalnej USA.

Słowa kluczowe: forward guidance, pułapka płynności, polityka monetarna, komunikacja.

\section{Wprowadzenie}

Ostatni kryzys finansowy oprócz negatywnych skutków gospodarczych przyniósł także liczne zmiany instytucjonalne. Nie ominęły one również niezwykle istotnej części polityki finansowej państwa, jaką jest polityka pieniężna. C. Borio [2011, s. V] zauważa, że kryzys postawił przed bankami centralnymi wyzwania natury ekonomicznej, intelektualnej i instytucjonalnej. Inny ekonomista, 
C. Goodhart [2010, s. 8], stawia hipotezę, że rezultatem obecnego kryzysu będzie „okres eksperymentów” w zakresie prowadzonej polityki monetarnej. Twierdzenia te znalazły odzwierciedlenie w rzeczywistości funkcjonowania banków centralnych w poszczególnych państwach.

Modyfikacjom w wykorzystywanym instrumentarium polityki monetarnej towarzyszyła ewolucja w komunikacji banku centralnego z otoczeniem. Należy pokreślić, że podejście do transparentności polityki monetarnej uległo zmianie znacznie wcześniej, jeszcze w latach 90. ubiegłego wieku. Obecny kryzys sprawił jednak, że skala i sposób komunikacji banków centralnych musiały zostać dostosowane do wymagającego otoczenia zewnętrznego. To także kryzys finansowy odpowiada za to, że coraz częściej w literaturze przedmiotu oraz praktyce bankowości centralnej forward guidance wskazywane jest jako istotne narzędzie polityki pieniężnej, w ramach którego bank centralny wyraźnie przedstawia otoczeniu swoje stanowisko w kwestii przyszłej polityki. Znaczenie to ujawnia się w szczególności w sytuacji tzw. pułapki płynności.

Celem niniejszego opracowania jest przedstawienie problematyki forward guidance, w szczególności w kontekście pułapki płynności. W pierwszej części przedstawiono problem efektywności polityki monetarnej w sytuacji skrajnie niskich stóp procentowych. Następnie opisana została ewolucja, jaka dokonała się w zakresie komunikacji banku centralnego z otoczeniem. W ostatniej części zaprezentowano teoretyczne oraz praktyczne aspekty forward guidance.

\section{Problem prowadzenia efektywnej polityki monetarnej w sytuacji stopy procentowej bliskiej zera}

Zgodnie ze współczesną praktyką banki centralne ogłaszają odpowiadającą celom polityki pieniężnej krótkookresową stopę procentową. Chcąc, aby stopa ta była efektywna, bank centralny wykorzystuje operacje zarządzania płynnością (liquidity management operations). W ten sposób kształtuje on zmienne ekonomiczne będące priorytetami w jego polityce. Sytuacja komplikuje się, gdy w wypadku występowania niskich poziomów inflacji połączonych z niskimi nominalnymi stopami procentowymi gospodarka doświadczy negatywnego szoku popytowego. Prawidłową reakcją banku centralnego na taką sytuację jest obniżenie realnych stóp procentowych. Jak zauważa L. Summers [1991, s. 625-632], przy powyższych założeniach dotyczących poziomu inflacji oraz nominalnych stóp procentowych bank centralny nie ma takiej możliwości, gdy wykorzystuje jedynie konwencjonalne narzędzia polityki monetarnej. Co jest niezwykle istotne w kontekście oceny działań banków centralnych w obliczu obecnego kryzysu, ostatnie lata przed jego wystąpieniem cechowały się relatywnie niskimi pozio- 
mami inflacji i nominalnych stóp procentowych w krajach rozwiniętych [Borio 2011, s. 5].

Problem nieefektywności polityki monetarnej w sytuacji skrajnie niskich stóp procentowych znalazł swoje odzwierciedlenie w teoretycznej konstrukcji określanej mianem pułapki płynności (liquidity trap). O możliwości zaistnienia wspomnianego zjawiska pisał już J.M. Keynes [1936] w Ogólnej teorii procentu, zatrudnienia i pieniqdza ${ }^{1}$. Do pułapki płynności dochodzi, gdy przy występującym niskim poziomie rynkowej stopy procentowej podmioty oczekują jej wzrostu w przyszłości. Wzrost ten oznacza spadek wartości oprocentowanych aktywów finansowych. Tak więc podmioty będą preferować gotówkę kosztem innych papierów wartościowych. Autorzy pracy [Duwendag i in. 1995, s. 58-59] uważają, że „krzywa preferencji płynności będzie wtedy doskonale elastyczna względem stopy procentowej (elastyczność ta będzie równa nieskończoności)" (rys. 1). Dodatkowo P. Krugman [1998, s. 137] zauważa, że ilość pieniądza nie odgrywa tu żadnej roli, gdyż zarówno on, jak i obligacje są perfekcyjnymi substytutami. Pułapka płynności jest „ekstremalną formą przejawiania się deflacji” [Gruszecki 2004, s. 182].

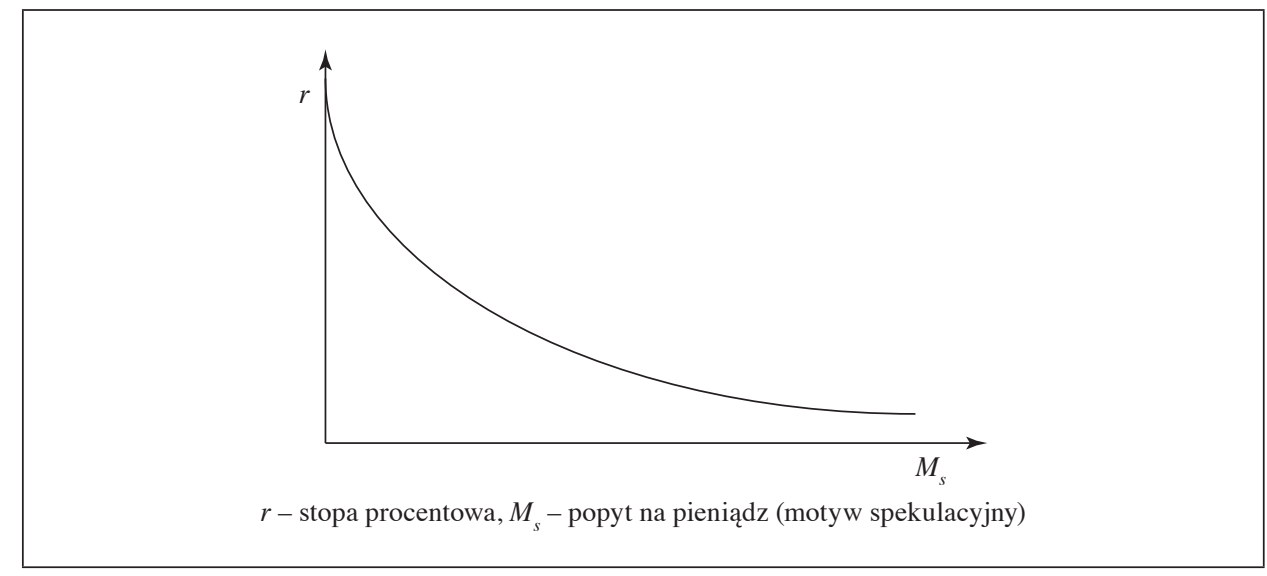

Rys. 1. Popyt na pieniądz w celach spekulacyjnych Źródło: [Duwendag i in. 1995, s. 58].

Problem efektywności polityki monetarnej w sytuacji pułapki płynności wynika z założenia podmiotów gospodarczych o braku możliwości spadku nominalnej stopy procentowej do wartości ujemnej. Takie twierdzenie ma także swoje podstawy teoretyczne. Jak zauważył I. Fisher [1930, s. 8], zerowa lub ujemna stopa

${ }^{1}$ J.M. Keynes nie używał jednak jeszcze pojęcia pułapki płynności. 
procentowa jest praktycznie niemożliwa. Według niego „stopa procentowa wyrażona w jednostkach danego aktywu zmierza do zera i nie spadnie nigdy poniżej tej wartości, jeśli koszt przechowywania tego aktywu jest równy zero" [Fisher 1930, s. 30]. Tak więc granicę tę wyjaśniają koszt utrzymania pieniądza oraz zachowanie krańcowej korzyści netto z pieniądza [Krawczyk 2013, s. 476].

Warto zwrócić uwagę, że w praktyce gospodarczej wystąpiło kilkakrotnie zjawisko ujemnej stopy procentowej. Po raz pierwszy ujemna nominalna stopa procentowa wystąpiła w Szwajcarii w 1979 r. [Kugler i Rich 2001, s. 2-3]. Do czasu obecnego kryzysu ujemna nominalna stopa procentowa pojawiła się także w Japonii pod koniec 1998 r. na rynku bonów skarbowych [Jorgensen i Risbjerg 2012, s. 61]. W rezultacie obecnego kryzysu finansowego liczba przypadków ujemnej nominalnej stopy procentowej zwiększyła się. Ujemna stopa wystąpiła na rynkach bonów skarbowych takich państw jak Szwajcaria, Niemcy i Dania [Jorgensen i Risbjerg 2012, s. 61]. P. Kugler oraz G. Rich [2001, s. 2] zauważają, że taką sytuację wyjaśnia istnienie kosztów transakcyjnych.

Jak zostało już wspomniane, sytuacja pułapki płynności sprawia, że konwencjonalne działania banku centralnego nie są efektywne. Bank centralny, aby przeciwdziałać procesom deflacyjnym w gospodarce, musi podejmować kroki o charakterze niekonwencjonalnym. Działania te obejmują m.in. zwiększenie bazy monetarnej, dewaluację krajowej waluty, a także forward guidance (zob. [Krawczyk 2013, Bernanke 2002]). Przejście do omówienia wykorzystania ostatniego z wymienionych narzędzi podczas kryzysu finansowego wymaga jednak w pierwszej kolejności przeanalizowania problemu komunikacji banku centralnego z otoczeniem w szerszym kontekście.

\section{Komunikacja banków centralnych z otoczeniem}

Do początku lat 90. XX w. bankowość centralna cechowała się brakiem przejrzystości i ukrywaniem rzeczywistych zamiarów organów decyzyjnych kształtujących politykę monetarną. Takie podejście wynikało z funkcjonującego w tamtym okresie konsensusu, zgodnie z którym bank centralny nie powinien informować podmiotów gospodarczych o swoich działaniach i ich motywacji. Twierdzenie to miało oparcie w dominującej wówczas teorii ekonomii. Po pierwsze, zgodnie z obowiązującymi modelami, w przypadku perfekcyjnego przewidywania przyszłości przez podmioty gospodarcze występuje niespójność polityki monetarnej w czasie. Autorzy takich modeli to m.in. F.E. Kydland i E.C. Prescott [1977, s. 473-492] oraz G.A. Calvo [1978, s. 1411-1428]. Ponadto, zgodnie z twierdzeniem A. Cukiermana i A. Meltzera [1986, s. 1099-1128], transparentność funkcjo- 
nowania organów władzy monetarnej ogranicza możliwość kreowania przez nie niespodzianek, a tym samym zmniejsza efektywność prowadzonej polityki.

O skali zjawiska ukrywania informacji przez bank centralny przed środowiskiem zewnętrznym świadczy chociażby tytuł książki W. Greidera - The Secrets of the Temple. Postawa taka pozostawała jednak w wyraźnej sprzeczności z postulatami banku centralnego jako instytucji funkcjonującej w ramach systemu demokratycznego. Wyrazem tego był pozew złożony przeciwko Federal Open Market Committee (FOMC) w amerykańskim Sądzie Najwyższym na podstawie ustawy o wolności informacji (Freedom of Information Act). Podczas wspomnianej rozprawy FOMC przedstawił argumenty przemawiające za ukrywaniem informacji przed opinią publiczną. Zostały one pogrupowane przez M. Goodfrienda [1984, s. 13] na pięć kategorii negatywnych efektów, które mogą być rezultatem transparentności. Były to:

- ,nieuczciwa spekulacja: tylko duży inwestor byłby w stanie wykorzystać udostępnione przez bank centralny informacje,

- niewłaściwa reakcja rynku: bieżące udostępnianie informacji może skutkować nadmierną albo przeciwną do zamierzonej przez FOMC reakcją rynku, reakcje rynku będą w rezultacie dużo trudniejsze do przewidzenia,

- niekorzystne efekty dla interesów rządu: ujawnianie informacji spowoduje reakcje rynku, które mogą zwiększyć koszty obsługi zadłużenia państwa oraz przeprowadzania operacji otwartego rynku,

- niepożądane przedwczesne zobowiązanie FOMC co do przyszłych działań,

- trudniejsze regulowanie stopą procentową przez bank centralny”.

Ostatecznie argumenty te nie przetrwały próby czasu. W ramach nowego konsensusu, który funkcjonuje w ekonomii od początku lat 90. ubiegłego wieku, uważa się, że to właśnie transparentność oraz komunikacja z otoczeniem są rozwiązaniem problemu niespójności polityki w czasie [Mishkin 2004, s. 2-4]. Ogłoszenie celów w zakresie frontu walki z inflacją pozwoliło bankom centralnym zwiększyć ich wiarygodność i ustabilizować oczekiwania inflacyjne [Levin, Natalucci i Piger 2004, s. 51]. R. Mohan [2009, s. 1-19] dodaje, że bankowość centralna oparta na sekretach i braku dostępu do informacji przestała przystawać do coraz większej roli sektora finansowego, która zmniejszała znaczenie tradycyjnej bankowości.

Zapoczątkowany w latach 90. proces zwiększania transparentności w funkcjonowaniu banków centralnych jest także kontynuowany w XXI w. Jak pokazują badania przeprowadzone przez N. Dincer oraz B. Eichengreena [2007, s. 32], poziom transparentności banków centralnych wzrósł we wszystkich grupach badanych krajów ${ }^{2}$, przy czym największy wzrost odnotowały kraje z grupy krajów wschodzących. Wynika stąd, że banki centralne coraz częściej używają komuni-

${ }^{2}$ Wspomniani autorzy podzieli państwa na trzy grupy: kraje rozwinięte (developed countries), kraje wschodzące (emerging countries) oraz kraje rozwijające się (developing countries). 
kacji z otoczeniem jako narzędzia polityki monetarnej. Zjawisko takiego oddziaływania na rynki przez bank centralny określone zostało mianem open mouth operations (operacje otwartych ust), co jest bezpośrednim nawiązaniem do open market operations (operacje otwartego rynku).

Prowadzona przez bank centralny komunikacja z otoczeniem może przyjmować różną formę, a także dotyczyć różnych obszarów jego działalności. Podstawowymi środkami, jakimi władze monetarne komunikują się z podmiotami gospodarczymi, są m.in. ogłoszenia decyzji, raporty, komunikaty, działalność w formie organu doradczego oraz inne formy interakcji z mediami [Mohan 2009, s. 2].

Banki centralne mogą informować podmioty gospodarcze o przyjętej strategii polityki monetarnej, planowanych działaniach ciał decyzyjnych oraz wynikach głosowań [Wesołowski i Żuk 2011, s. 5-6]. Ze względu na temat niniejszego opracowania dalszej analizie poddane zostało narzędzie forward guidance.

\section{Charakterystyka forward guidance}

Od początku lat 90. ubiegłego wieku w komunikacji banków centralnych z otoczeniem, jak to określił F. Mishkin [2004, s. 1], mamy do czynienia z rewolucją. Jednym $\mathrm{z}$ jej objawów jest analizowane w teorii, ale także stosowane w praktyce narzędzie polityki monetarnej, jakim jest forward guidance. M. Woodford [2012, s. 3] określa je jako wyraźne stanowisko banku centralnego w kwestii jego przyszłej polityki. Jest ono dodatkiem do oświadczeń dotyczących obecnej polityki banku. Pojęcie forward guidance w literaturze odnosi się jednak najczęściej wyłącznie do polityki stopy procentowej prowadzonej przez bank centralny (zob. [Coeurè 2013] $)^{3}$. Również w niniejszym opracowaniu problem komunikowania prognoz dotyczących przyszłych decyzji władz monetarnych zawężony został do kwestii polityki stóp procentowych.

Forward guidance jest narzędziem polityki monetarnej wykorzystywanym zarówno jako środek ujawniania przez bank centralny posiadanych przez niego prywatnych informacji, jak i jako forma zobowiązywania się przez bank do prowadzenia określonej polityki w przyszłości [Kool i Thornton 2012 s. 2-6]. Stosowanie forward guidance związane jest z próbą oddziaływania banku centralnego na długookresowe stopy procentowe. Jak bowiem zauważa M. Woodford [1999, s. 14], zagregowany popyt zależy w większym stopniu od oczekiwanych długookresowych realnych stóp procentowych niż od występujących w danym okresie

\footnotetext{
${ }^{3}$ Podział na interest rate forward guidance (forward guidance dotyczący polityki stopy procentowej) i balance sheet forward guidance (forward guidance dotyczący polityki bilansu banku centralnego) powstał dopiero w rezultacie obecnego kryzysu finansowego i związanego z próbami jego zwalczania wykorzystywania polityki bilansu banku centralnego przez władze monetarne.
} 
stóp krótkoterminowych. Z kolei oczekiwane długookresowe stopy procentowe, zgodnie z teorią oczekiwań (hipotezą oczekiwań) Fishera, zależą od prognozowanych przyszłych krótkoterminowych stóp procentowych. Forward guidance jest więc narzędziem, które w sposób bardziej precyzyjny pozwala bankowi centralnemu kontrolować długoterminowe stopy procentowe. Dodatkowo forward guidance bardzo dobrze wpisuje się w koncepcję banku centralnego jako instytucji demokratycznej, ze względu na ujawnianie przez bank posiadanych informacji. Zaletą forward guidance jest także możliwość wpłynięcia na oczekiwania podmiotów gospodarczych w sytuacji, gdy nie są one zgodne z intencjami banku centralnego [Courè 2013].

Uzyskanie korzyści z wykorzystania forward guidance zależy od trzech czynników wymienionych przez A. Filarda oraz B. Hofmanna [2014, s. 38]. Po pierwsze, forward guidance musi być postrzegane przez podmioty gospodarcze jako przyrzeczenie banku centralnego. Po drugie, musi być ono zakomunikowane w sposób wyraźny. Po trzecie, skuteczność forward guidance zależy od sposobu jego interpretacji przez podmioty gospodarcze (czy jest ono zgodne z założeniami banku centralnego).

Oprócz wspomnianych korzyści wynikających z wykorzystywania analizowanego narzędzia polityki monetarnej, omawiane narzędzie niesie ze sobą także pewne trudności oraz zagrożenia. Jak zauważają F. Mishkin [2004, s. 9-11] oraz C. Goodhart [2001, s. 167], ustalenie prognozy dla przyszłych stóp procentowych przez organy kształtujące politykę pieniężną może stanowić wielką trudność w praktyce. W ten sposób nadmiernie zostałby skomplikowany proces podejmowania decyzji ${ }^{4}$. Ponadto podmioty gospodarcze mogą zinterpretować zaproponowaną przyszłą politykę stóp procentowych jako niezależną od pozostałych zmiennych ekonomicznych. Taka sytuacja może skutkować spadkiem wiarygodności banku centralnego w sytuacji, gdy zmiana realiów ekonomicznych w przyszłości zmusi go do zmiany wcześniej przedstawionej ścieżki stopy procentowej [Mishkin 2004, s. 11-13]. Dodatkowo forward guidance może ograniczać elastyczność działań banku centralnego [Gersbach i Hahn 2008, s. 2].

Komunikowanie planowanych działań ciał decyzyjnych banku centralnego może przyjmować różne formuły. Jedną z nich jest publikowanie przez banki centralne przyszłej ścieżki stóp procentowych (ilościowy forward guidance). Pierwszym krajem, który zdecydował się na taką formułę, była Nowa Zelandia w 1997 r. Po niej ścieżkę przyszłej stopy procentowej zaczęła publikować Kolumbia (w latach 2003-2004) [Mishkin 2004, s. 4]. Do chwili obecnej grono państw publikujących ścieżkę przyszłych stóp procentowych powiększyło się

\footnotetext{
${ }^{4}$ Inne stanowisko w tej sprawie przedstawia L. Svensson [2001]. Jego zdaniem decyzje dotyczące kształtu opublikowanej ścieżki przyszłych stóp procentowych mogą odbywać się w ramach procedury „prostego” głosowania.
} 
o Norwegię (2005 r.), Szwecję (2007 r.), Islandię (2007 r.), Czechy (2008 r.) oraz Izrael $(2008 \mathrm{r} .)^{5}$.

Z kolei A. Filardo i B. Hofmann [2014, s. 40] wyróżniają trzy podstawowe formy forward guidance:

- niezawierające szczegółowych informacji ilościowych dotyczących ścieżki stopy procentowej oraz ram czasowych (jakościowe), np. ,polityka stopy procentowej będzie utrzymana na obecnym poziomie przez dłuższy okres",

- zawierające ramy czasowe (calendar-based),

- oparte na wartościach zmiennych z gospodarki realnej (threshold-based).

\section{Forward guidance w okresie kryzysu finansowego}

Zdecydowany wzrost znaczenia forward guidance nastąpił dopiero w rezultacie obecnego kryzysu finansowego i będących jego konsekwencją procesów deflacyjnych. Liczni teoretycy bankowości centralnej podkreślają, że to właśnie w sytuacji, w której znalazły się władze monetarne znacznej części państw, tj. w środowisku stóp procentowych obniżonych do minimów oraz narastających procesów deflacyjnych, szczególną rolę odegrać ma narzędzie forward guidance. Do tego grona zaliczają się m.in. B. Bernanke i V. Reinhart [2004, s. 85-86] ${ }^{6}$. Jak podkreśla B. Cœurè [2013], premia za prowadzenie klarownej komunikacji z otoczeniem jest szczególnie duża w sytuacjach skrajnych, takich jak: posiadanie stóp procentowych na poziomie (lub blisko) ich dolnej efektywnej granicy, niesprawność normalnych kanałów transmisji monetarnej lub występowanie wyjątkowej niepewności co do stanu gospodarki. Ze względu na fakt, że takie sytuacje występują niezwykle rzadko, podmiotom gospodarczym trudno jest prognozować samodzielnie przeszłą ścieżkę stopy procentowej w oparciu o historyczne zależności. Taką hipotezę potwierdzają także przeciwnicy stosowania forward guidance w ,normalnych czasach” - T. Ito i F. Mishkin [2004]. Stoją oni na stanowisku, że w sytuacji środowiska deflacyjnego działania takie są niezbędne w celu powstrzymania procesów deflacyjnych.

W okresie kryzysu finansowego, ze względu na omawiane powyżej problemy w zakresie stosowania konwencjonalnej polityki monetarnej, grono banków stosujących forward guidance poszerzyło się ${ }^{7}$. Co niezmiernie istotne, narzędzie to

${ }^{5}$ Informacje o bankach centralnych publikujących własną prognozę przyszłej polityki stopy procentowej podawane za [Grosta, Niedźwiedzińska i Stawasz 2012, Moessner, Hann i Jansen 2014, The Impact... 2007].

6 Zob. także prace [Svensson 2001, Eggertsson i M. Woodford 2003, Woodford 2003].

7 Bankiem centralnym, który jako pierwszy stosował politykę forward guidance w sytuacji skrajnie niskich stóp procentowych, był Bank Japonii pod koniec XX w. Także Fed stosował tym- 
znalazło się w instrumentarium tak znaczących dla światowej gospodarki banków centralnych, jak: Bank Anglii, Bank Japonii, Europejski Bank Centralny oraz System Rezerwy Federalnej USA. Należy podkreślić, że wdrażane przez wymienione banki formuły forward guidance różniły się od siebie. Taka sytuacja wynika po części z celów przypisanych działaniu poszczególnych banków. Ze względu na znaczenie Fed w światowej gospodarce oraz na fakt, że dokonywał on istotnych zmian w wykorzystywanym forward guidance, będzie on przedmiotem dalszej analizy.

Fed pod przewodnictwem B. Bernankego zdecydował się na zastosowanie forward guidance w grudniu $2008 \mathrm{r}$. W przedstawionym opinii publicznej komunikacie zawarto informację, że Federal Open Market Committee przewiduje, iż występujące słabe warunki gospodarcze prawdopodobnie gwarantują wyjątkowo niskie poziomy stopy federal funds (stopa procentowa funduszy federalnych) przez pewien czas. Podobny komunikat ukazał się także 18 marca 2009 r. Tym razem jednak Fed dodatkowo wskazał precyzyjnie na planowany do utrzymania poziom federal funds rate, to jest przedział od 0 do $0,25 \%$, oraz użył zwrotu extended period (wydłużony okres). Tego rodzaju forward guidance określane jest także mianem open-ended, gdyż nie wskazuje na ewentualny czas zakończenia polityki niskich stóp procentowych. W sierpniu 2011 r. Fed zdecydował się przejść z open-ended na calendar-based forward guidance. Komunikat FOMC zawierał informację, że w rezultacie niskiego wykorzystania mocy produkcyjnych oraz słabej presji inflacyjnej w średnim okresie stopy procentowe pozostaną na wyjątkowo niskim poziomie co najmniej do połowy $2013 \mathrm{r}$. W komunikatach ze stycznia 2012 r., a także sierpnia 2012 r. FOMC podał informację o przedłużeniu wskazanego terminu odpowiednio do połowy $2014 \mathrm{r}$. i połowy $2015 \mathrm{r}$.

W 2011 r. C. Evans [2011] zaproponował, aby Fed zobowiązał się do utrzymania stóp procentowych na niezmienionym poziomie do momentu, gdy bezrobocie przestanie przekraczać $7 \%$ i poziom rocznej inflacji w średnim terminie czasu nie przekroczy 3\% (tzw. reguła Evansa lub 7/3 threshold rule). Ostatecznie amerykański bank centralny zdecydował się przyjąć zmodyfikowaną wersję „reguły Evansa” 12 grudnia 2012 r. Fed postanowił zastąpić 7-procentowy poziom bezrobocia 6,5-procentowym, 3-procentowy poziom inflacji 2,5-procentowym oraz uzupełnić regułę o zapis wskazujący na konieczność utrzymania stabilnych długoterminowych oczekiwań inflacyjnych. W grudniu 2013 r. warunek dotyczący inflacji zastąpiono formułą, zgodnie z którą stopy procentowe pozostaną na niezmienionym poziomie, dopóki prognozowana inflacja nie przekroczy $2 \%$ długoterminowego celu FOMC. Ostatecznie 19 marca 2014 r. FOMC zrezygnowała $\mathrm{Z}$, ,reguły Evansa” opartej na poziomie bezrobocia występującego w gospopoczątku XXI w. istniało zagrożenie deflacji w gospodarce amerykańskiej. 
darce ${ }^{8}$. W obecnie wykorzystywanej formule forward guidance FOMC wskazuje, że przyszłe decyzje dotyczące stóp procentowych zależą od szeroko rozumianej kondycji rynku pracy ${ }^{9}$, wskaźników określających stopień presji inflacyjnej i oczekiwań inflacyjnych oraz rozwoju sytuacji na rynku finansowym.

W literaturze przedmiotu istnieją różne wyniki badań przedstawiających efekty funkcjonowania forward guidance w różnych państwach oraz okresach. Analizy dokonane przez C. Koola i D. Thortona [2012, s. 1-40] oraz M. Anderssona i B. Hofmanna [2009, s. 1-44] wykazały, że forward guidance nie zwiększa skuteczności polityki monetarnej w Nowej Zelandii. Pierwsza grupa badaczy udowodniła jednak, że w przypadku Norwegii i Szwecji narzędzie to zwiększyło zdolności predykcyjne uczestników rynku do poziomu krótkookresowych stóp procentowych (w krótkim horyzoncie czasowym). Z kolei badania przeprowadzone na Islandii wykazały, że forward guidance znacząco zwiększyło wpływ polityki monetarnej na oczekiwania podmiotów rynkowych dotyczące polityki stopy procentowej, tym samym zwiększając zdolności kształtowania długoterminowych stóp procentowych [The Impact... 2007]. Także badania przeprowadzone przez A. Filardo oraz B. Hofmanna [2014, s. 1-17], obejmujące takie banki centralne jak Fed, EBC, BoE i BoJ, potwierdzają, że forward guidance ma wpływ na oczekiwaną przyszłą stopę procentową (decyduje więc o poziomie długoterminowej stopy procentowej). Jednak, jak zauważają badacze, wpływ ten jest zróżnicowany w zależności od kraju oraz okresu stosowania forward guidance. Zwracają oni także uwagę na takie niebezpieczeństwa wynikające ze stosowania tej formy polityki monetarnej, jak zmiany reakcji rynku finansowego na informacje płynące ze sfery realnej ${ }^{10}$ i niestabilność rynku finansowego ${ }^{11}$.

Badania prowadzone nad gospodarką szwedzką przez R. Moessnera, J. de Hanna i D.J. Jansena [2014, s. 1-13] wykazały jednak, że forward guidance nie wpłynęło znacząco na czułość na napływające informacje na rynku swapów stopy procentowej. Dodatkowo badania R. Gürkaynaka, B. Sacka i E. Swansona [2004, s. 1-19], C. Branda, D. Buncica i J. Turunena [2010, s. 1-19] oraz M. Bibin-

${ }^{8}$ Wynikało to po części z faktu, że poziom bezrobocia w ostatnich miesiącach zbliżył się do 6,5\% (w lutym 2014 r. wyniósł 6,7\%).

9 Forward guidance rozszerzone zostało o dodatkowe parametry z rynku pracy, takie jak np. poziom wskaźnika aktywności zawodowej oraz udział bezrobotnych pozostających bez pracy przez co najmniej 27 tygodni w całkowitej populacji bezrobotnych.

${ }^{10}$ Przykładem tego jest zwiększenie wrażliwości rynku finansowego na dane dotyczące poziomu zatrudniania, które wynikało z formuły forward guidance w postaci „reguły Evansa”.

${ }^{11}$ Podkreślają oni jednak, że forward guidance może zwiększyć niestabilność sektora finansowego głównie w sposób pośredni przez to, że jego stosowanie może przyczynić się do opóźnienia podwyżki stóp procentowych. 
gera, T. Linzereta i L. Winkelmanna [2013, s. 1-18] potwierdziły, że wpływa ono na długoterminową stopę procentową.

\section{Podsumowanie}

Liczba banków centralnych wykorzystujących forward guidance wzrasta. Po części jest to rezultatem występowania problemu prowadzenia efektywnej polityki monetarnej w sytuacji skrajnie niskich stóp procentowych. W literaturze brak konsensusu co do efektów takiego działania. Wynika to m.in. z różnych form, w jakich banki centralne implementują wskazane narzędzie.

Oceniając przydatność forward guidance, należy przede wszystkim porównać je do innych instrumentów proponowanych jako rozwiązania problemu nieefektywności polityki konwencjonalnej w sytuacji stopy procentowej bliskiej (lub równej) zeru. Niewątpliwie przewagą forward guidance nad polityką luzowania ilościowego (QE) jest fakt, że nie generuje ono gwałtownego zwiększenia bilansu banku centralnego. Co więcej, M. Bauer oraz G. Rudebusch [2013, s. 1-24] w swoich badaniach udowodnili, że QE oddziałuje poprzez „kanał sygnalizacyjny" (signaling channel) ${ }^{12}$. A. Filardo oraz B. Hofmann [2014, s. 38] sugerują więc, że forward guidance można traktować jako substytut QE, lecz nieobarczony problemem wzrostu bilansu banku centralnego ${ }^{13}$. W kontekście ewentualnych negatywnych efektów forward guidance ma także zdecydowaną przewagę nad propozycją wprowadzenia ujemnej nominalnej stopy procentowej banku centralnego, w szczególności biorąc pod uwagę negatywne konsekwencje implementacji ujemnej stopy w postaci zamrożenia akcji kredytowej w gospodarce w wyniku osłabienia pozycji finansowej banków komercyjnych.

Pomimo związanych z forward guidance zagrożeń niewątpliwe jest, że powinno ono znaleźć się $\mathrm{w}$ instrumentarium banku centralnego w sytuacji stóp procentowych bliskich zera. Jest ono bowiem efektywnym narzędziem kształtowania oczekiwań, a jak powiedział M. Woodford [2003, s. 15]: „,nie tylko oczekiwania są istotne w przypadku polityki monetarnej, ale w obecnej sytuacji wszystko inne znaczy niewiele".

12 Podkreślić należy jednak, że zdecydowana większość badań nad QE zwraca uwagę na port folio balance channel (zob. [Kimura i Small 2004]).

${ }^{13}$ Wspomniani autorzy stawiają jednak pytanie, czy w rzeczywistości forward guidance może być na tyle silnie „sygnalizującym” narzędziem jak QE. 


\section{Literatura}

Andersson M., Hofmann B. [2009], Gauging the Effectiveness of Quantitative Forward Guidance. Evidence from Three Inflation Targeters, „ECB Working Paper Series”, nr 1098.

Bauer M., Rudebusch G. [2013], The Signaling Channel for Federal Reserve Bond Purchases, ,Federal Reserve Bank of San Francisco Working Paper Series”, 2011-21.

Bernanke B. [2002], Deflation: Makin Sure „It” Doesn't Happen Here, wypowiedź podczas spotkania Krajowego Klubu Ekonomicznego, Waszyngton, 21 listopada.

Bernanke B., Reinhart V. [2004], Conducting Monetary Policy at Very Low Short-term Interest Rates, „AEA Papers and Proceedings”, vol. 94, nr 2, http://dx.doi.org/10.1257/ 0002828041302118.

Bibinger M., Linzert T., Winkelmann L. [2013], ECB Monetary Policy Surprises: Identification through Cojumps in Interest Rates, ,SFB 649 Discussion Paper”, nr 38.

Borio C. [2011], Central Banking Post-crisis: What Compass for Uncharted Waters? „Bank for International Settlements Working Papers”, nr 353.

Brand C., Buncic D., Turunen J. [2010], The Impact of ECB Monetary Policy Decisions and Communication on the Yield Curve, ,Journal of the European Economic Association", vol. 8, nr 6.

Calvo G.A. [1978], On the Time Consistency of Optimal Policy in a Monetary Economy, „Economietrica”, vol. 46, nr 6, http://dx.doi.org/10.2307/1913836.

Cœurè B. [2013], The Usefulness of Forward Guidance, przemówienie przed Money Marketeers Club of New York, 26 września.

Cukierman A., Meltzer A. [1985], A Theory of Ambiguity, Credibility, and Inflation under Discretion and Asymmetric Information, „Econometrica”, vol. 54, nr 4.

Dincer N.N., Eichengreen B. [2007], Central Bank Transparency: Where, Why, and with What Effects? „NBER Working Paper Series”, nr 13003.

Duwendag D., Ketterer K.H., Kösters W., Pohl R., Simmert, D.B. [1995], Teoria pieniqdza i polityka pieniężna, Poltext, Warszawa.

Eggertsson G., Woodford M., [2003], The Zero Bound on Interest Rates and Optimal Monetary Policy, „Brookings Papers on Economic Activity”, nr 1.

Evans C. [2011], The Fed's Dual Mandate Responsibilities and Challenges Facing US Monetary Policy, „European Economics and Financial Centre Distinguished Speaker Seminar”, London, 7 września, http://www.chicagofed.org/webpages/publications/ speeches/2011/09 07 dual-mandate-.cfm (data dostępu: 1.04.2014).

Filardo A., Hofmann B. [2014], Forward Guidance at the Zero Lower Bound, „,BIS Quarterly Review", marzec.

Fisher I. [1930], The Theory of Interest, The Macmillan, New York.

Gersbach H., Hahn V. [2008], Forward Guidance for Monetary Policy: Is It Desirable? „CER-ETH Working Paper”, nr 84, http://dx.doi.org/10.2139/ssrn.1115829.

Goodfriend M. [1984], Monetary Mystique: Secrecy and Central Banking, „Federal Reserve Bank of Richmond Working Paper", 85-7.

Goodhart C. [2001], Monetary Transmission Lags and the Formulation of the Policy Decision on Interest Rates, „Federal Reserve Bank of St. Louis Review”, lipiec/ sierpień.

Goodhart C. [2010], The Changing Role of Central Banks, „Bank for International Settlements Working Papers", nr 326. 
Grostal W., Niedźwiedzińska J., Stawarz E. [2012], Zmiany w strategii i polityce komunikacyjnej FED, Narodowy Bank Polski, Instytut Ekonomiczny, Biuro Strategii Polityki Pieniężnej, 11 kwietnia.

Gruszecki T. [2004], Teoria pieniqdza i polityka pieniężna. Rys historyczny i praktyka gospodarcza, Oficyna Ekonomiczna, Kraków.

Gürkaynak R.S., Sack B., E. Swanson [2004], Do Actions Speak Louder than Words? The Response of Asset Prices to Monetary Policy Actions and Statements, „Finance and Economics Discussion Series Federal Reserve Board", Waszyngton.

Ito T., Mishkin F. [2004], Monetary Policy in Japan: Problem and Solutions, „Center on Japanese Economy and Business Working Paper", Columbia University.

Jorgensen A., Risbjerg L. [2012], Negative Interest Rates, „Monetary Review”, 3rd Quarter, Part 1, Danmarks Nationalbank.

Keynes J.M. [1936], The General Theory of Employment, Interest and Money, Macmillan Cambridge University Press.

Kimura T., Small D. [2004], Quantitative Monetary Easing and Risk in Financial Asset Markets, „Finance and Economics Discussion Series”, Divisions of Research and Statistics and Monetary Affairs, Federal Reserve Board, Waszyngton.

Kool C.J.M, Thornton D.L. [2012], How Effective Is Central Bank Forward Guidance? „Federal Reserve Bank of St. Louis Working Paper Series”, nr 2012-063A.

Krawczyk M. [2013], O polityce fiskalnej i pieniężnej w warunkach pułapki płynności, „Ekonomista", nr 4.

Krugman P. [1998], It's Baaack: Japan's Slump and the Return of the Liquidity Trap, „Brookings Papers on Economic Activity”, nr 2.

Kugler P., Rich G. [2001], Monetary Policy under Low Interest Rates: The Experience of Switzerland in the Late 1970s, artykuł zaprezentowany na „Ausschuss für Geldtheorie und Geldpolitik - Verein für Socialpolitik”, Frankfurt am Main, 16/17 lutego.

Kydland F.E., Prescott E.C. [1977], Rules Rather than Discretion: The Inconsistency of Optimal Plans, ,The Journal of Political Economy”, vol. 85, nr 3, http://dx.doi. org/10.1086/260580.

Levin A., Natalucci F., Piger J. [2004], The Macroeconomic Effects of Inflation Targeting, „Federal Reserve Bank of St. Louis Review”, lipiec/sierpien, vol. 84, nr 4.

Mishkin F. [2004], Can Central Bank Transparency Go too Far? „NBER Working Paper Series", nr 10892.

Moessner R., de Hann J., Jansen D.J. [2014], The Effect of the Zero Lower Bound, Forward Guidance and Unconventional Monetary Policy on Interest Rate Sensitivity to Economic News In Sweden, „DNB Working Paper”, $\mathrm{nr} 413$.

Mohan R. [2009], Communications in Central Banks: A Perspective, Stanford Center for International Development Working Paper, nr 408.

Summers L. [1991], How Should Long-term Monetary Policy Be Determined? „Journal of Money and Banking", nr 23, cz. II.

Svensson L. [2001], The Zero Bound in an Open Economy: A Foolproof Way of Escape From a Liquidity Trap, „Monetary and Economic Studies”, nr 2.

The Impact of the Publication of Central Bank's Policy Rate Path on Forward Interest Rates and the Effectiveness of Monetary Policy [2007], ,Sedlabanki Monetary Bulletin", nr 3. 
Wesołowski G., Żuk P. [2011], Rola komunikacji banków centralnych z otoczeniem, Narodowy Bank Polski, Instytut Ekonomiczny, Biuro Strategii Polityki Pieniężnej, 29 listopada.

Woodford M. [1999], Optimal Monetary Policy Interia, NBER Working Paper Series, nr 7261 .

Woodford M. [2003], Interest Rates and Prices: Foundations of a Theory of Monetary Policy, Princeton University Press, Nowy Jork.

Woodford M. [2012], Methods of Policy Accommodation at Interest-rate Lower Bound, „Columbia University Working Paper”, wrzesień.

\section{Forward Guidance as a Monetary Policy Tool at the Zero Lower Boundary}

Beyond the negative economic consequences it brought about, the current financial crisis has also contributed to a number of institutional changes. This evolution in the institutional framework has also appeared in monetary policy. With interest rates nearing their lower boundary, central banks have started to use unconventional monetary policy tools. One such tool is introduced in this article, which provides the theoretical background and features of forward guidance. The article contains information about the usage of forward guidance during the financial crisis. In this context, forward guidance is presented based on the experience of the Federal Reserve.

Keywords: forward guidance, liquidity trap, monetary policy, communication. 